\title{
ANALISIS FAKTOR-FAKTOR PENERIMAAN PENGGUNAAN APLIKASI ANDROID BOOK KEEPER ACCOUNTING DENGAN PENDEKATAN TECHNOLOGY ACCEPTANCE MODEL PADA UMKM DI KOTA PONTIANAK
}

\author{
Angga Permadi Karpriana \\ Fakultas Ekonomi dan Bisnis Universitas Tanjungpura
}

\begin{abstract}
ABSTRAK
Penggunaan aplikasi Android Book Keeper Accounting diharapkan dapat membantu pemilik UMKM di Kota Pontianak dalam mengelola keuangan. Penelitian ini bertujuan untuk mengetahui faktor-faktor yang mempengaruhi pemilik UMKM di Kota Pontianak untuk berminat menggunakan aplikasi Android Book Keeper Accounting. Technology Acceptance Model (TAM) digunakan sebagai model untuk menguji penerimaan teknologi aplikasi Android Book Keeper. Metode penelitian ini menggunakan survey dengan teknik pengambilan sampel 100 responden mewakili tiap-tiap kecamatan di Kota Pontianak. Hasil analisis data enelitian diperoleh hasil sebagai berikut: (1) Konstruk perceived ease of use (PEOU) mempengaruhi konstruk perceived usefulness (PU); (2) Konstruk PU mempengaruhi konstruk attitude towards behavior (ATB); (3) Konstruk perceived ease of use (PEOU) mempegaruhi terhadap konstruk attitude towards behavior (ATB); (4) Konstruk PU mempengaruhi terhadap konstruk behavior intention (BI); (5) Konstruk attitude towards behavior (ATB) tidak memiliki pengaruh terhadap konstruk behavior intention (BI). Faktor-faktor pendorong konstruk attitude towards behavior (ATB) masih kurang kuat sehingga tidak berpengaruh terhadap minat perilaku pemilik UMKM untuk menggunakan aplikasi Android Book Keeper Accounting.
\end{abstract}

Kata Kunci : Technology Acceptance Model (TAM), Book Keeper Accounting, pemilik UMKM 


\section{PENDAHULUAN}

Perkembangan teknologi informasi mengalami kemajuan yang sangat cepat. Kemajuan tersebut dapat dilihat dari perubahan produk teknologi informasi berupa gadget yang setiap tahun semakin canggih fitur-fiturnya. Kecanggihan fitur-fitur hardware pada gadget diikuti dengan pengembangan software sistem operasi atau Operation System (OS) dan aplikasi-aplikasi pendukungnya yang semakin canggih. Kepraktisan dan mobilitas kerja menjadi pertimbangan pengguna gadget untuk mendukung aktivitas kerja. Bentuk gadget berupa laptop, tablet dan smartphone semakin ringkas dan praktis dibawa lebih diminati oleh pengguna.

Menurut data yang diperoleh International Data Corporation (IDC) Indonesia, memperkirakan penjualan smartphone di Indonesia mencapai 34 juta unit pada 2016 atau tumbuh $21 \%$ dibandingkan 2015 sebanyak 28 juta unit (sumber: www.indotelko.com). Keadaaan ini menggambarkan bahwa setiap tahun lebih dari 10\% dari penduduk Indonesia merupakan konsumen smartphone baru. Pengguna smartphone atau tablet di Indonesia meningkat setiap tahunnya sehingga kebutuhan informasi oleh masyarakat juga meningkat. Kebutuhan informasi khususnya di bidang bisnis dan perdagangan semakin meningkat sehingga pelaku bisnis memerlukan sistem informasi yang menyediakan data keuangan internal dan eksternal perusahaan.

Sistem informasi yang dipilih perusahaan tidak secara otomatis akan langsung berjalan sesuai dengan tujuannya. Proses adaptasi perusahaan terhadap sistem informasi dan teknologi informasi memerlukan waktu untuk mempersiapkan sumber daya manusia dan infrastruktur pendukungnya. Proses adopsi teknologi dan sistem informasi oleh sumber daya perusahaan dipengaruhi oleh reaksi dan persepsi terhadap penerimaan penggunaan teknologi dan sistem informasi tersebut.

Aplikasi Android Book Keeper Accounting merupakan aplikasi keuangan pada smartphone atau tablet yang membantu pengusaha untuk mengolah keuangan usahanya. Aplikasi tersebut dapat diunduh secara gratis melalui google playstore. Penerimaan penggunaan aplikasi Book Keeper Accounting oleh pengusaha UMKM khususnya mikro dan kecil merupakan reaksi dan persepsi dalam penerimaan sistem informasi yang digunakan. 
Sistem informasi memberi kemudahan bagi pengusaha untuk mengolah data transaksi perusahaan menjadi data keuangan. Pengolahan data transaksi bisnis pengusaha UMKM (Usaha Mikro Kecil dan Menengah) khususnya usaha mikro dan kecil, masih dilakukan dengan cara manual berupa catatan dan dipindahkan ke database komputer setelah operasional kegiatan bisnis berakhir. Pemindahan data manual ke data digital sangat rentan terjadi kehilangan data, keterlambatan input, dan akurasi entry data. Pengusaha mikro dan kecil akan memilih teknologi informasi berupa tablet dan smartphone yang mendukung sistem informasi. Tablet dan smartphone yang dilengkapi dengan aplikasi keuangan akan sangat membantu pengusaha mikro dan kecil untuk mencatat data transaksi harian bisnis.

UMKM sebagai pendukung perekonomian daerah dan nasional harus mampu menggunakan sistem informasi agar dapat berkelanjutan dan mempunyai keunggulan bersaing. Pengolahan data yang cepat dan akurat dengan dukungan sistem informasi berbasis aplikasi keuangan pada Android menjadikan UMKM mampu mengolah data keuangan dan menyajikan informasi keuangan. UMKM di Kota Pontianak dipilih menjadi obyek penelitian ini karena perkembangannya yang fluktuatif. UMKM di Kota Pontianak harus mengolah data transaksi keuangannya dengan baik sehingga dapat mempertahankan kelanjutan usaha dan mengembangkannya.

UMKM skala mikro dan kecil di Kota Pontianak mengalami kendala dalam pengolahan data keuangan dikarenakan keterbatasan modal, pengetahuan dan infrastruktur pendukung sistem informasi. UMKM skala mikro dan kecil cenderung menggunakan pengolahan data keuangan secara manual dibandingkan menggunaskan sistem informasi sederhana pada aplikasi Android yang salah satunya Book Keeper Accounting. Masih sangat jarang UMKM skala mikro dan kecil menggunakan aplikasi Android Book Keeper Accounting untuk mengelola data keuangan perusahaan.

Tingkat penerimaan dan penggunaan terhadap aplikasi Android Book Keeper Accounting oleh UMKM di Kota Pontianak dapat diukur dengan pendekatan teori Technology Acceptance Model (TAM). Permasalahan-permasalahan yang ada selanjutnya akan dianalisis dengan menggunakan model TAM. Variabel-variabel yang digunakan dalam menganalisis penelitian ini merupakan variabel yang terdapat dalam TAM yang terd iri dari Variabel Independen (eksogen) dan Variabel Dependen (endogen). 
Terdapat satu variabel independen yaitu Kemudahan Pengguna Persepsian (Perceived Ease of Use) Sedangkan, variabel dependen terdiri dari Kegunaan Persepsian (Perceived Usefulness), Sikap Terhadap Penggunaan Teknologi (Attitude Towards Behavior), dan Minat Perilaku Menggunakan Teknologi (Behavioral Intention).

Berdasarkan latar belakang di atas maka dapat dirumuskan permasalahan sebagai berikut:

1. Apakah kemudahan pengguna persepsian (perceived ease of use) berpengaruh terhadap kegunaan persepsian (perceived usefulness)?

2. Apakah kegunaan persepsian (perceived usefulness) berpengaruh terhadap sikap terhadap penggunaan teknologi (attitude towards behavior)?

3. Apakah kemudahan pengguna persepsian (perceived ease of use) berpengaruh terhadap sikap terhadap penggunaan teknologi (attitude towards behavior)?

4. Apakah kegunaan persepsian (perceived usefulness) berpengaruh terhadap minat perilaku menggunakan teknologi (behavioral intention)?

5. Apakah kegunaan persepsian (perceived usefulness) berpengaruh terhadap minat perilaku menggunakan teknologi (behavioral intention)?

Penelitian ini berkontribusi dalam memberikan masukan mengenai gambaran faktor-faktor penerimaan dan penggunaan sistem informasi Book Keeper Accounting oleh UMKM di Kota Pontanak dalam mendukung aktivitas bisnisnya. Serta menjadi kajian ilmiah bagi penelitian selanjutnya mengenai faktor-faktor penerimaan dan penggunaan sistem informasi Book Keeper Accounting.

\section{TINJAUAN PUSTAKA}

\section{Sistem Informasi}

Menurut Gordon (1990) menyatakan bahwa Sistem Informasi Manajemen adalah sebuah sistem manusia atau mesin yang terpadu untuk menyajikan informasi guna mendukung fungsi operasi manajemen dan pengambilan keputusan dalam suatu organisasi.

Sistem informasi menurut Mcleod (1992) menyatakan bahwa Sistem Informasi merupakan sistem yang mempunyai kemampuan untuk mengumpulkan informasi dari semua sumber dan menggunakan berbagai media untuk menampilkan informasi. 
Turban (1999) dalam Abdul Kadir (2002) menyatakan bahwa sebuah sistem informasi mengumpulkan, memproses, menyimpan, menganalisis, dan menyebarkan informasi untuk tujuan yang spesifik.

Hall (2001) dalam Abdul Kadir (2002) menyatakan bahwa sistem informasi adalah sebuah rangkaian prosedur formal di mana data dikelompokkan, diproses menjadi informasi, dan didistribusikan kepada pemakai.

Menurut Jogiyanto (2009 : 11) dalam bukunya yang berjudul "Analisis dan Desain Sistem Informasi" menyatakan:

Sistem informasi adalah suatu sistem di dalam suatu organisasi yang mempertemukan kebutuhan pengolahan transaksi harian, mendukung operasi, bersifat manajerial dan kegiatan strategi suatu organisasi dan menyediakan pihak luar tertentu dengan laporan - laporan yang diperlukan.

Definisi akuntansi adalah proses pengidentifikasian, pengukuran, pencatatan dan pelaporan transaksi ekonomi (keuangan) dari suatu organisasi/entitas yang dijadikan sebagai informasi dalam rangka pengambilan keputusan ekonomi oleh pihak-pihak yang memerlukan, termasuk analisis atas laporan tersebut. Sedangkan sistem informasi akuntansi merupakan penerapan sistem informasi dalam pelaporan transaksi ekonomi (keuangan) dari suatu organisasi/entitas yang dijadikan sebagai informasi yang dibutuhkan oleh pihak-pihak yang memerlukan, termasuk analisis atas laporan tersebut. Menurut Gordon B. Davis dalam Jogiyanto (2009 : 15) mengemukakan definisi sistem informasi manajemen adalah manusia atau mesin menyediakan informasi untuk mendukung operasi, manajemen dan fungsi pengambilan keputusan dari suatu organisasi.

\section{Technology Acceptance Model (TAM)}

Technology Acceptance Model (TAM) merupakan suatu model penerimaan sistem teknologi informasi yang akan digunakan oleh pemakai. TAM dikembangkan oleh Davis et al. berdasarkan model theory of reasoned action (TRA). TAM menambahkan dua konstruk utama ke dalam model TRA. Dua konstruk utama ini adalah kegunaan persepsian (perceived usefulness) dan kemudahan penggunaan persepsian (perceived ease of use) (Davis et al, 1989: 320). 
Kegunaan persepsian (perceived usefulness) dan kemudahan penggunaan persepsian (perceived ease of use) keduanya mempunyai pengaruh ke niat perilaku (behavioral intention). Kemudahan penggunaan persepsian (perceived ease of use) mempengaruhi kegunaan persepsian (perceived usefulness). Model dari TAM dapat dilihat di Gambar 1 berikut:

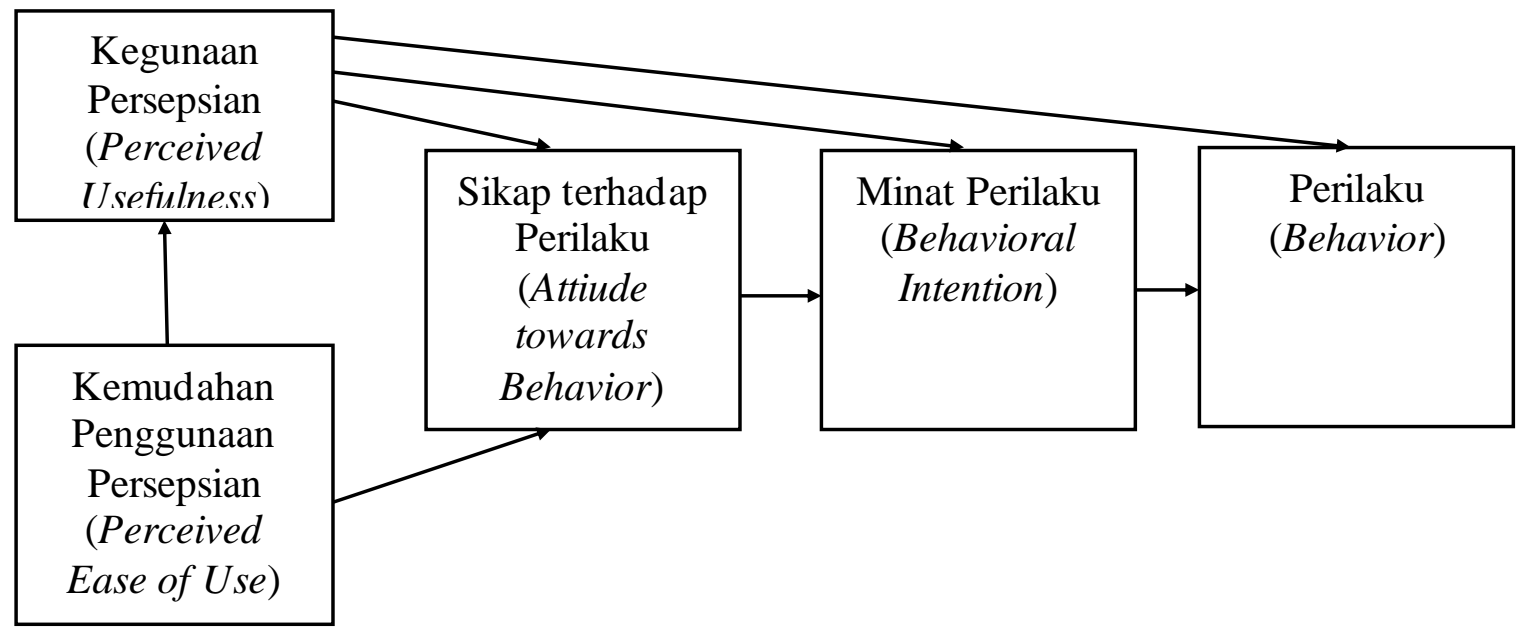

Sumber : Davis et al, 1989: 320

\section{Gambar 2.1. Hubungan antar konstruk TAM}

Technology Acceptance Model (TAM) menggunakan lima konstruk utama. Kelima konstruk tersebut adalah sebagai berikut:

1. Kegunaan persepsian (perceived usefulness)

Kegunaan persepsian (perceived usefulness) didefinisikan sebagai sejauh mana seseorang percaya bahwa menggunakan suatu teknologi akan meningkatkan kinerja pekerjaannya ("as the extent to which a person believes that using a technology will enhance her or his performance.") Dengan demikian jika seseorang percaya bahwa sistem informasi berguna maka dia akan menggunakannya. Penelitian-penelitian sebelumnya menunjukkan bahwa konstruk kegunaan persepsian (perceived usefulness) mempengaruhi secara positif dan signifikan terhadap penggunaan sistem informasi (misalnya Davis, 1989; Chau, 1996; Igbaria et al., 1997; Sun, 2003). Penelitianpenelitian sebelumnya juga menunjukkan bahwa kegunaan persepsian (perceived usefulness) merupakan konstruk yang paling banyak signifikan dan penting yang mempengaruhi sikap (attitude), niat (behavioral intention), dan perilaku (behavior) di dalam menggunakan teknologi dibandingkan dengan konstruk lainnya. Sebaliknya, 
penelitian Karahna dan Limayem pada tahun 2000 yang menggunakan variabel karakteristik tugas dalam penelitiannya memperoleh hasil bahwa penentu penggunaan sistem informasi dengan konstruk PU dan PEOU berbeda untuk tugas-tugas yang berbeda (Jogiyanto, 2008: 126). Davis menggunakan 6 buah item untuk membentuk konstruk ini. Keenam item tersebut adalah Work More Quickly, Job Performance, Increase Productivity, Effectiveness, Makes Job Easier, dan Useful.

2. Kemudahan penggunaan persepsian (perceived ease of use)

Kemudahan penggunaan persepsian (perceived ease of use) didefinisikan sebagai sejauh mana seseorang percaya bahwa menggunakan suatu teknologi akan bebas dari usaha ("is the extent to which a person believes that using a technology will be free of effort.") Dapat disimpulkan bahwa jika seseorang merasa percaya bahwa sistem informasi mudah digunakan maka dia akan menggunakannya. Penelitian-penelitian sebelumnya menunjukan bahwa konstruk kemudahan penggunaan persepsian (perceived ease of use) mempengaruhi kegunaan persepsian (perceived usefulness), sikap (attitude), niat (behavioral intention), dan penggunaan sesungguhnya (behavior). Walaupun pada penelitian Chau dan $\mathrm{Hu}$ pada tahun 2002 tentang penggunaan teknologi telemedicine oleh dokter-dokter di Hongkong mendapatkan hasil yang sebaliknya (Jogiyanto, 2008: 217). Seperti halnya pada konstruk kegunaan persepsian (perceived usefulness), Davis menggunakan 6 buah item untuk membentuk konstruk ini. Keenam item tersebut adalah Easy of Learn, Controllable, Clear \& Understandable, Flexible, Easy to Become Skillful, dan Ease to Use.

3. Sikap terhadap perilaku (attitude towards behavior) atau sikap menggunakan teknologi (attitude towards using technology)

Sikap terhadap perilaku (attitude towards behavior) didefinisikan oleh Davis et al. (1989: 319-339) sebagai perasaan-perasaan positif atau negatif dari seseorang jika harus melakukan perilaku yang akan ditentukan ("an individual's positive or negative feelings about performing the target behavior.") Sedangkan, Mathieson (1991: 173-191) mendefinisikan sikap terhadap perilaku (attitude towards behavior) sebagai evaluasi pemakai tentang ketertarikannya menggunakan sistem ("the user's evaluation of the desirability of his or her using the system.") Penelitian-penelitian sebelumnya menunjukkan bahwa sikap (attitude) ini berpengaruh secara positif ke niat perilaku 
(behavioral intention). Namun, menurut Ajzen (dalam Jogiyanto, 2008: 27), banyak sekali perilaku-perilaku yang dilakukan oleh manusia di luar kemauan kontrolnya. Perilaku tersebut dinamakan perilaku kewajiban (mandatory behavior), perilaku yang diwajibkan adalah perilaku yang bukan atas kemauannya sendiri tetapi karena memang tuntutan atau kewajiban dari kerja.

4. Minat perilaku (behavioral intention) atau niat perilaku menggunakan teknologi (behavioral intention to use)

Niat perilaku (behavioral intention) adalah suatu keinginan (niat) seseorang untuk melakukan suatu perilaku yang tertentu. Seseorang akan melakukan suatu perilaku (behavior) jika mempunyai keinginan atau niat (behavioral intention) untuk melakukannya. Penelitian-penelitian sebelumnya menunjukkan bahwa niat perilaku (behavioral intention) merupakan prediksi yang baik dari penggunaan teknologi oleh pemakai sistem.

5. Perilaku (behavior) atau penggunaan teknologi sesungguhnya (actual technology use)

Perilaku (behavior) adalah tindakan yang dilakukan oleh seseorang. Dalam konteks penggunaan sistem teknologi informasi, perilaku (behavior) adalah penggunaan sesungguhnya (actual use) dari teknologi. Karena penggunaan sesungguhnya tidak dapat diobservasi oleh peneliti yang menggunakan daftar pertanyaan, maka penggunaan sesungguhnya ini banyak diganti dengan nama pemakaian persepsian (perceived usage). Davis pada tahun 1989 menggunakan pengukuran pemakaian sesungguhnya (actual usage), dan Igbaria et al. pada tahun 1995 menggunakan pengukuran pemakaian persepsian (perceived usage) yang diukur sebagai jumlah waktu yang digunakan untuk berinteraksi dengan suatu teknologi dan frekuensi penggunaannya. Szajna pada tahun 1994 menyarankan menggunakan dilaporkan-sendiri (self-reported usage) sebagai pengganti penggunaan sesungguhnya (actual usage). 


\section{Usaha Mikro, Kecil dan Menengah (UMKM)}

Definisi UMKM menurut Undang-Undang Nomor 20 tahun 2008 tentang Usaha Mikro Kecil dan Menengah Pasal 1 ayat 1,2, dan 3 yaitu:

1. Dalam Pasal 1 ayat 1

"Usaha Mikro adalah usaha produktif milik orang perorangan dan/atau badan usaha perorangan yang memenuhi Usaha Mikro, sebagaimana diatur dalam Undang-Undang ini."

2. Dalam Pasal 1 ayat 2

"Usaha Kecil adalah usaha ekonomi produktif yang berdiri sendiri, yang dilakukan oleh orang perorangan atau badan usaha yang bukan merupakan anak perusahaan atau bukan cabang perusahaan yang dimiliki, dikuasai atau menjadi bagian baik langsung maupun tidak langsung dari usaha menengah atau usaha besar yang memenuhi kriteria usaha kecil sebagaimana dimaksud dalam undang-undang ini."

3. Dalam Pasal 1 ayat 3

"Usaha Menengah adalah usaha ekonomi produktif yang berdiri sendiri, yang dilakukan oleh orang perseorangan atau badan usaha yang bukan merupakan anak perusahaan atau cabang perusahaan yang dimiliki, dikuasai atau menjadi bagian baik langsung maupun tidak langsung dengan usaha kecil atau besar dengan jumlah kekayaan bersih atau hasil penjualan tahunan sebagaimana diatur dalam undangundang ini."

Kriteria Usaha Mikro, Kecil dan Menengah yang telah tertuang pada pasal 6 Undang-Undang Nomor 20 tahun 2008 tentang Usaha Mikro Kecil dan Menengah yaitu :

a. Usaha Mikro adalah :

1. Memiliki kekayaan bersih paling banyak Rp 50.000.000 (lima puluh juta rupiah) termasuk tanah dan bangunan tempat usaha; atau;

2. Memiliki hasil penjualan tahunan paling banyak Rp 300,000.000 (tiga ratus juta rupiah).

b. Usaha Kecil adalah :

1. Memiliki kekayaan bersih lebih dari Rp 50.000.000 (lima puluh juta rupiah sampai dengan paling banyak Rp500.000.000,00 (lima ratus juta rupiah) tidak termasuk tanah dan bangunan tempat usaha; atau 
2. Memiliki hasil penjualan tahunan lebih dari Rp300.000.000,00 (tiga ratus juta rupiah) sampai dengan paling banyak Rp2.500.000.000,00 (dua milyar lima ratus juta rupiah).

c. Usaha Menengah adalah :

1. Memiliki kekayaan bersih lebih dari Rp50.000.000,00 (lima puluh juta rupiah) sampai dengan paling banyak Rp500.000.000,00 (lima ratus juta rupiah) tidak termasuk tanah dan bangunan tempat usaha; atau

2. Memiliki hasil penjualan tahunan lebih dari Rp300.000.000,00 (tiga ratus juta rupiah) sampai dengan paling banyak Rp2.500.000.000,00 (dua milyar lima ratus juta rupiah).

\section{Partial Least Square (PLS)}

Partial Least Square (PLS) atau disebut juga dengan variance based SEM yang berbasis komponen atau varian. Ghozali mengemukakan bahwa PLS merupakan pendekatan alternative yang bergeser dari pendekatan SEM berbasis kovarian menjadi berbasis varian (Ghozali, 2006: 4).PLS bagus digunakan untuk menganalisiis data dengan ukuran sampel kecil maupun besar serta cocok digunakan untuk semua jenis skala data baik nominal maupun ordinal. PLS merupakan metode analisis data yang powerfull karena tidak didasarkan pada banyak asumsi (Ghozali, 2006: 4). Walaupun PLS digunakan untuk mengkonfirmasi teori, tetapi PLS juga dapat digunakan untuk menjelaskan ada atau tidaknya hubungan antara variabel laten.

Perbedaan yang mendasar dari pendekatan PLS dengan covariance based SEM adalah pada tujuannya. Pendekatan PLS bertujuan untuk melakukan prediksi apakah ada hubungan antara konstruk-konstruk (variabel) yang digunakan pada penelitian, sedangkan covariance based SEM bertujuan untuk mengkonfirmasi suatu teori apakah teori tersebut cocok dengan data hasil observasi yang dilakukan.

Terd apat dua model indikator dalam pendekatan partial least square (PLS), yaitu: 
1. Model Indikator Refleksif

Model indikator refleksif dikembangkan berdasarkan pada classical test theory yang mengasumsikan bahwa variasi skor pengukuran konstruk merupakan fungsi dari true score ditambah error. Ciri-ciri dari model indikator reflektif adalah, arah hubungan kausalitas seolah-olah dari konstruk ke indikator, antar indikator diharapkan saling berkolerasi (memiliki internal consistency reliability), menghilangkan satu indikator dari model pengukuran tidak akan mengubah makna dan arti konstruk, dan menghitung adanya kesalahan pengukuran (error) pada tingkat indikator.

Model indikator refleksif harus memiliki internal konsistensi dikarenakan semua ukuran indikator diasumsikan sebagai valid indikator yang mengukur suatu konstruk, sehingga dua ukuran indikator yang sama reliabilitasnya dapat saling dipertukarkan. Walaupun reliabilitas (cronbach alpha) suatu konstruk akan rendah jika hanya ada sedikit indikator, tetapi validitas konstruk tidak akan berubah jika satu indikator dihilangkan.

2. Model Indikator Formatif

Konstruk dengan indikator formatif mempunyai karakteristik berupa komposit, seperti yang digunakan dalam literatur ekonomi yaitu index of sustainable economics welfare, the human development index, dan the quality of life index. Pada model formatif variabel komposit seolah-olah dipengaruhi (ditentukan) oleh indikatornya. Jadi arah hubungan kausalitas seolah-olah dari indikator ke variabel laten. Ciri-ciri model indikator formatif yaitu arah hubungan kausalitas seolah-olah dari indikator ke konstruk, antar indikator diasumsikan tidak berkorelasi (tidak diperlukan uji konsistensi internal atau alpha cronbach), menghilangkan satu indikator berakibat merubah makna dari konstruk, dan kesalahan pengukuran diletakkan pada tingkat konstruk.

Terdapat dua model spesifikasi PLS, yaitu model struktural atau disebut inner model dan model pengukuran atau disebut outer model.

1. Model Struktural (Inner Model)

Model struktural atau inner model menggambarkan hubungan antar konstruk laten berdasarkan pada teori. Perancangan model struktural hubungan 
antar konstruk laten didasarkan pada rumusan masalah atau hipotesis penelitian (Ghozali, 2006: 23).

2. Model Pengukuran (Outer Model)

Model pengukuran atau outer model mendefinisikan bagaimana setiap blok indikator berhubungan dengan konstruk latennya. Perancangan model pengukuran menentukan sifat indikator dari masing-masing konstruk laten, apakah refleksif atau formatif, berdasarkan definisi operasional variabel (Ghozali, 2006: 23).

\section{Hipotesis Penelitian}

Berdasarkan kerangka TAM yang dikembangakan oleh F. Davis maka dapat dirumuskan hipotesis penelitian sebagai berikut:

H1 : Kemudahan pengguna persepsian (perceived ease of use) mempunyai pengaruh positif terhadap kegunaan persepsian (perceived usefulness) dalam penggunaan Book Keeper Accounting.

$\mathrm{H} 2$ : Kegunaan persepsian (perceived usefulness) mempunyai pengaruh positif terhadap sikap terhadap sikap terhadap perilaku (attitude towards behavior) dalam penggunaan Book Keeper Accounting.

H3 : Kemudahan pengguna persepsian (perceived ease of use) mempunyai pengaruh positif terhadap sikap terhadap sikap terhadap perilaku (attitude towards behavior) dalam penggunaan Book Keeper Accounting.

H4 : Kegunaan persepsian (perceived usefulness) mempunyai pengaruh positif terhadap sikap terhadap minat perilaku (behavioral intention) dalam penggunaan Book Keeper Accounting.

H5 : Sikap terhadap perilaku (attitude towards behavior) mempunyai pengaruh positif terhadap sikap terhadap minat perilaku (behavioral intention) dalam penggunaan Book Keeper Accounting

\section{METODE PENELITIAN}

Penelitian ini dilakukan di Kota Pontianak, Kalimantan Barat. Alasan dipilihnya Kota Pontianak sebagai lokasi penelitian karena belum banyak UMKM di Kota Pontianak menggunakan sistem informasi. Populasi dalam penelitian ini adalah seluruh 
UMKM yang berada di Kota Pontianak. UMKM yang menjadi populasi penelitian berada di enam kecamatan Kota Pontianak yaitu: Pontianak Kota, Pontianak Timur, Pontianak Barat, Pontianak Utara, Pontianak Selatan, dan Pontianak Tenggara.

Pemilihan sampel dalam penelitian ini menggunakan teknik cluster sampling dan purposive random sampling yaitu mengambil 20 UMKM disetiap enam kecamatan di Kota Pontianak secara acak yang sesuai dengan kriteria sebagai berikut:

1. Usaha Mikro dan Kecil

2. Belum menggunakan Sistem Informasi

3. Memiliki gadget (tablet atau smartphone)

Sehingga diperoleh sampel penelitian sebanyak 120 UMKM di Kota Pontianak.

Pengumpulan data yang dilakukan dalam penelitian ini adalah dengan menggunakan metode survey yaitu dengan menyebarkan secara langsung daftar pertanyaan berupa kuesioner tertutup yang akan diisi oleh pemilik UMKM di Kota Pontianak. Pertanyaan berkaitan dengan data demografi responden serta tanggapan responden terhadap faktor-faktor penerimaan dan penggunaan aplikasi Android Book Keeper Accounting.

Variabel penelitian ini terdiri atas 1 konstruk eksogen (independen) dan 3 konstruk endogen (dependen) yaitu:

1. Kemudahan penggunaan persepsian (perceived ease of use) (PEOU)

Kemudahan penggunaan persepsian (perceived ease of use) didefinisikan sebagai sejauh mana seseorang percaya bahwa menggunakan suatu teknologi akan bebas dari usaha (Davis, 1986). Kemudahan penggunaan persepsian adalah bagian dari faktor TAM yang merupakan variabel unobserved sehingga memerlukan variabel manifest dalam pengukurannya. Variabel manifest dalam penelitian ini diadopsi dari enam item pertanyaan yang dikembangkan Davis et al. (1986).

2. Kegunaan persepsian (perceived usefulness) (PU)

Kegunaan persepsian (perceived usefulness) didefinisikan sebagai sejauh mana seseorang percaya bahwa menggunakan suatu teknologi akan meningkatkan kinerja pekerjaannya (Davis, 1986). Kegunaan persepsian adalah bagian dari faktor TAM yang merupakan variabel unobserved sehingga memerlukan variabel manifest 
dalam pengukurannya. Variabel manifest dalam penelitian ini diadopsi dari enam item pertanyaan yang dikembangkan Davis et al. (1986).

3. Sikap terhadap Perilaku (attiude towards behavior) (ATB)

Sikap terhadap perilaku (attitude towards behavior) didefinisikan oleh Davis et al. (1989) sebagai perasaan-perasaan positif atau negatif dari seseorang jika harus melakukan perilaku yang akan ditentukan. Variabel manifest dalam penelitian ini diadopsi dari empat item pertanyaan yang dikembangkan Taylor dan Todd (1995).

4. Minat perilaku (behavioral intention) (BI)

Minat perilaku menggunakan teknologi (behavioral intention to use) adalah suatu keinginan (niat) seseorang untuk melakukan suatu perilaku yang tertentu. Variabel manifest dalam penelitian ini diadopsi dari tiga item pertanyaan yang dikembangkan Taylor dan Todd (1995).

Keempat variabel tersebut diukur menggunakan 7 poin derajat skala likert yaitu dari skala $1=($ Sangat Tidak Setuju/Tidak Sering Digunakan/ Sangat Tidak Memadai/Sangat Rendah) sampai dengan skala $7=$ (Sangat Setuju /Sering Digunakan/Sangat Memadai/Sangat Tinggi).

Analisis data penelitian ini sebagai berikut:

1. Uji Kualitas Data

Untuk menguji kualitas data maka digunakan 2 uji, terdiri atas:
a. Uji Validitas
b. Uji Reliabilitas

2. Partial Least Square (PLS)

Penelitian ini menggunakan pendekatan PLS untuk menganalisis data. Tahapan analisis data yang selanjutnya akan dilakukan dengan menggunakan software smartPLS sebagai berikut :

a. Perancangan Model Struktur(Inner Model)

Model struktural atau inner model menggambarkan hubungan antar konstruk laten berdasarkan pada teori. Perancangan model struktural hubungan antar konstruk laten didasarkan pada rumusan masalah atau hipotesis penelitian. 
b. Perancangan Model Pengukuran (Outer Model)

Model pengukuran atau outer model mendefinisikan bagaimana setiap blok indikator berhubungan dengan konstruk latennya. Perancangan model pengukuran menentukan sifat indikator dari masing-masing konstruk laten berdasarkan definisi operasional variabel. Sifat indikator dari masing-masing konstruk pada penelitian ini adalah refleksif.

\section{HASIL PENELITIAN DAN PEMBAHASAN}

\section{Hasil Penelitian}

Penelitian ini menggunakan data primer yang berbentuk kuesioner. Penyebaran kuesioner melalui teknik sampling sehingga diperoleh 100 responden UMKM yang mewakili tiap-tiap kecamatan di Kota Pontianak. Pelaksanaan survey untuk memperoleh data primer ini dilakukan mulai 2 Agustus 2016 hingga 5 September 2016. Deskripsi data dapat dilihat pada Tabel 4.1.

Data responden pada konstruk perceived ease of use (PEOU) terdiri atas 6 pernyataan dengan skor minimum data adalah 2 , skor maksimum data dalah 7 . Skor ratarata konstruk perceived ease of use (PEOU) dari 6 pernyataan yaitu: terendah 5,24 dan tertinggi 5,30. Simpangan baku konstruk perceived ease of use (PEOU) dari 6 pernyataan yaitu: terendah 1,122 dan tertinggi 1,367 .

Data responden pada konstruk perceived usefulness (PU) terdiri atas 6 pernyataan dengan skor minimum data adalah 2, skor maksimum data dalah 7. Skor rata-rata konstruk perceived usefulness (PU) dari 6 pernyataan yaitu: terendah 5,10 dan tertinggi 5,44. Simpangan baku konstruk perceived usefulness (PU) dari 6 pernyataan yaitu: terendah 1,000 dan tertinggi 1,269.

Data responden pada konstruk attiude towards behavior (ATB) terdiri atas 4 pernyataan dengan skor minimum data adalah 2, skor maksimum data dalah 7. Skor ratarata konstruk attiude towards behavior (ATB) dari 4 pernyataan yaitu: terendah 5,27 dan tertinggi 5,32. Simpangan baku konstruk attiude towards behavior (ATB) dari 4 pernyataan yaitu: terendah 1,127 dan tertinggi 1,411 . 
Tabel 4.1

Deskripsi Data

\begin{tabular}{|l|c|c|c|c|c|}
\hline & $\mathrm{N}$ & Minimum & Maximum & Mean & Std. Deviation \\
\hline PEOU1 & 100 & 2 & 7 & 5,25 & 1,336 \\
\hline PEOU2 & 100 & 2 & 7 & 5,24 & 1,311 \\
\hline PEOU3 & 100 & 2 & 7 & 5,27 & 1,230 \\
\hline PEOU4 & 100 & 2 & 7 & 5,29 & 1,122 \\
\hline PEOU5 & 100 & 2 & 7 & 5,27 & 1,302 \\
\hline PEOU6 & 100 & 2 & 7 & 5,30 & 1,367 \\
\hline PU1 & 100 & 2 & 7 & 5,44 & 1,234 \\
\hline PU2 & 100 & 2 & 7 & 5,19 & 1,169 \\
\hline PU3 & 100 & 2 & 7 & 5,10 & 1,000 \\
\hline PU4 & 100 & 2 & 7 & 5,34 & 1,199 \\
\hline PU5 & 100 & 2 & 7 & 5,44 & 1,234 \\
\hline PU6 & 100 & 2 & 7 & 5,37 & 1,269 \\
\hline ATB1 & 100 & 2 & 7 & 5,27 & 1,127 \\
\hline ATB2 & 100 & 2 & 7 & 5,32 & 1,197 \\
\hline ATB3 & 100 & 2 & 7 & 5,30 & 1,411 \\
\hline ATB4 & 100 & 2 & 7 & 5,30 & 1,345 \\
\hline Bl1 & 100 & 2 & 7 & 5,23 & 1,118 \\
\hline BI2 & & & 7 & 5,33 & 1,190 \\
\hline BI3 & 100 & & & & \\
\hline
\end{tabular}

Sumber: Data Olahan SPSS

Data responden pada konstruk behavioral intention (BI) terdiri atas 3 pernyataan dengan skor minimum data adalah 2, skor maksimum data dalah 7. Skor rata-rata konstruk behavioral intention (BI) dari 3 pernyataan yaitu: terendah 5,23 dan tertinggi 5,33. Simpangan baku konstruk behavioral intention (BI) dari 3 pernyataan yaitu: terendah 1,118 dan tertinggi 1,345. 


\section{Pengujian Persyaratan Analisis}

\section{Perancangan Inner Model}

Perancangan inner model hubungan antar konstruk didasarkan pada rumusan masalah atau hipotesis penelitian. Perancangan inner model dengan menggunakan software smartPLS dapat dilihat pada Gambar 4.1.

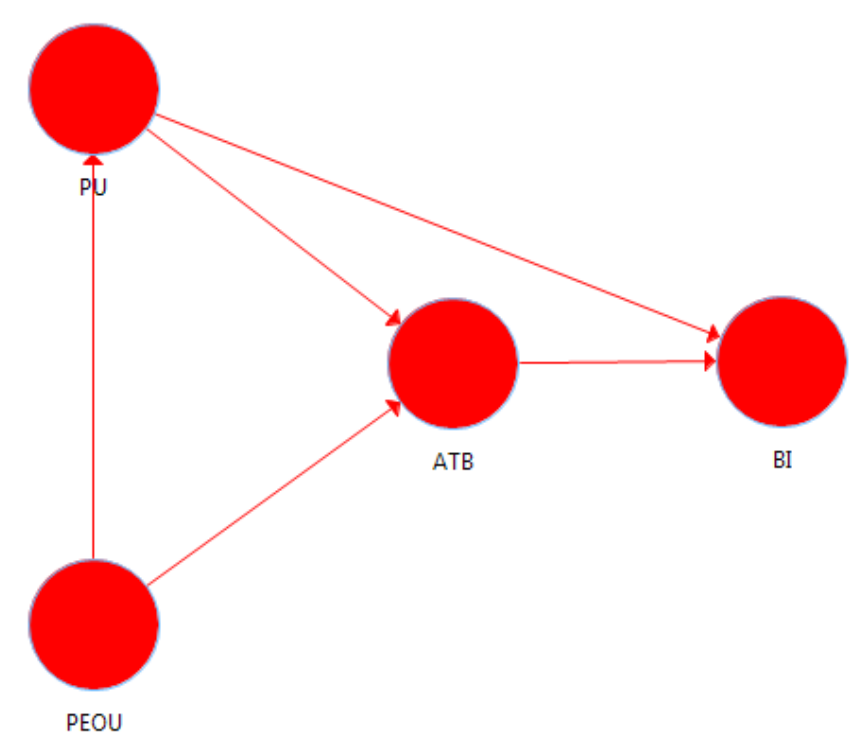

Sumber: Data Olahan SmartPLS

\section{Gambar 4.1 Perancangan Inner Model}

\section{Perancangan Outer Model}

Indikator dari masing-masing konstruk yaitu konstruk PEOU, PU, ATB, d an BI pada outer model bersifat refleksif. Sehingga arah panah pada model pengukuran dari arah konstruk menuju indikator. Perancangan outer model dengan menggunakan software smartPLS dapat dilihat pada Gambar 4.2. 


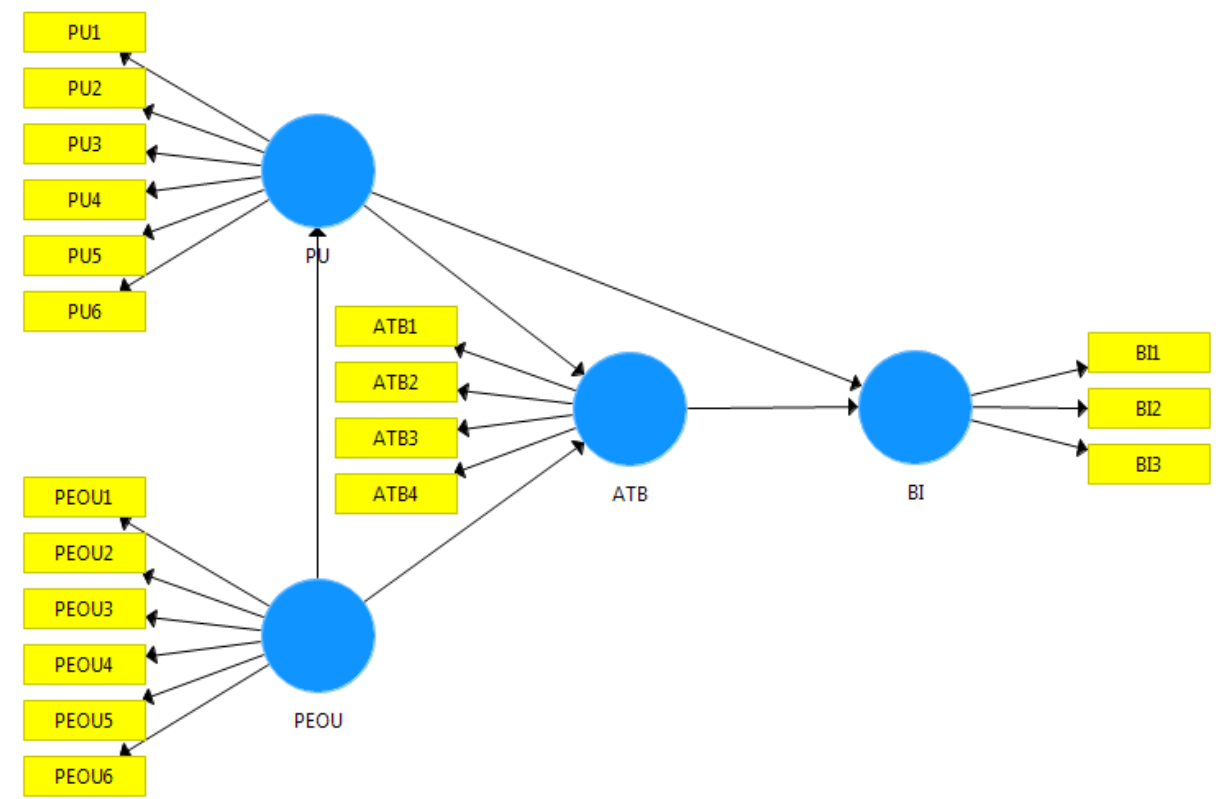

Sumber: Data Olahan SmartPLS

Gambar 4.2 Perancangan Outer Model

\section{Estimasi Model}

Metode pendugaan parameter (estimasi model) dalam penelitian ini menggunakan PLS Algorithm pada software smartPLS. Ketentuan untuk menguji unidimensionalitas dari masing-masing konstruk dengan melihat convergent validity dari masing-masing indikator konstruk.

Kriteria ukuran refleksif individual dikatakan tinggi jika berkorelasi lebih besar dari 0,70 dengan konstruk yang diukur. Kriteria loading factor 0,50 sampai 0,60 masih dapat dipertahankan untuk model yang masih dalam tahap pengembangan (Chin, 1998). Hasil estimasi model dengan PLS Algorithm dapat dilihat pada Gambar 4.3. 


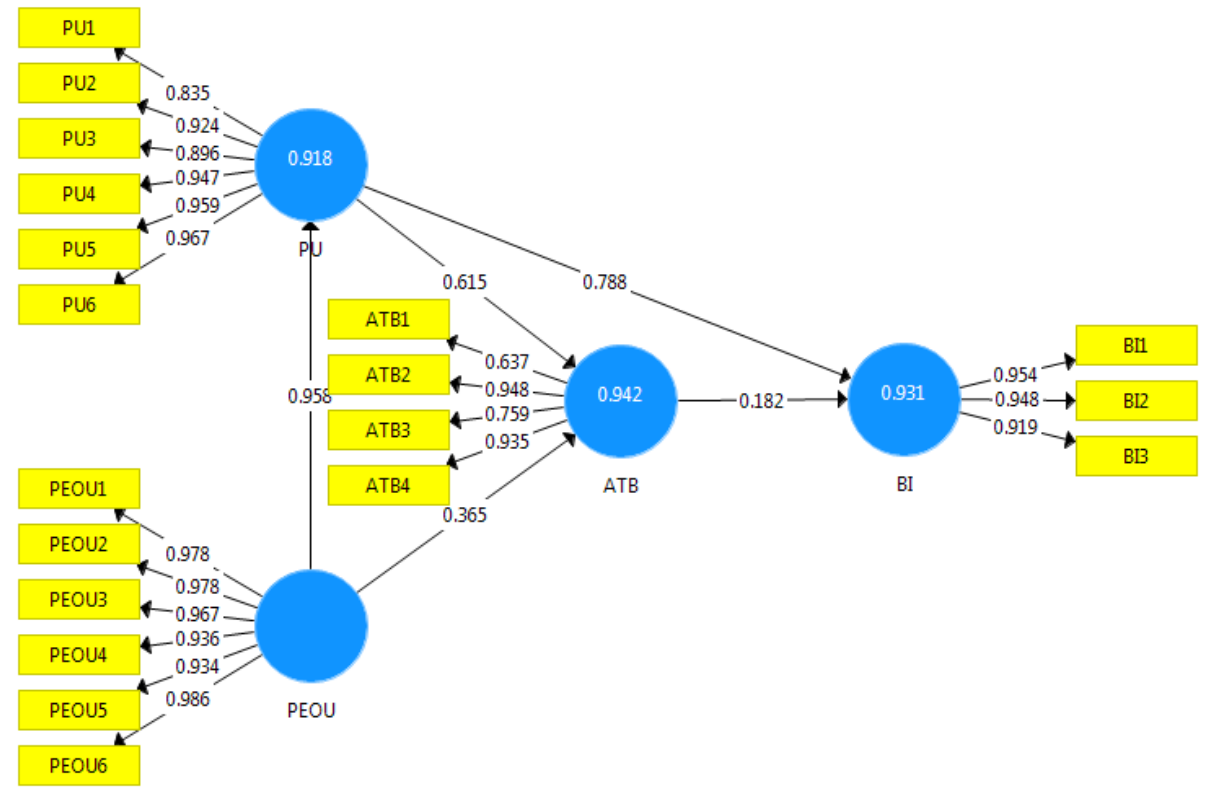

Sumber: Data Olahan SmartPLS

Gambar 4.3 Leading Factor Estimasi Model

Hasil estimasi model menunjukan bahwa tidak ada indikator dengan loading factor di bawah 0,50 sehingga model dapat dievaluasi

\section{Evaluasi Model}

Evaluasi model untuk outer model dan inner model selanjutnya dilakukan dengan membaca hasil report kalkulasi dari PLS Algorithm sebagai berikut:

\section{a. Pengujian Outer Model}

Terdapat 3 kriteria untuk mengevaluasi outer model dengan indikator refleksif yaitu convergent validity, discriminant validity, dan composite reliability. Convergent validity dari measurement model dengan indikator refleksif dapat dilihat dari korelasi antara skor item atau indikator dengan konstruknya (loading factor) yang dapat dilihat dari output outer loadings. Output outer loadings dari hasil estimasi PLS Algorithm dapat dilihat pada Tabel 4.2. 
Tabel 4.2

Output Outer Loadings

\begin{tabular}{|l|l|l|l|l|}
\hline & ATB & BI & PEOU & PU \\
\hline ATB1 & 0,637 & & & \\
\hline ATB2 & 0,948 & & & \\
\hline ATB3 & 0,759 & & & \\
\hline ATB4 & 0,935 & & & \\
\hline BI1 & & 0,954 & & \\
\hline BI2 & & 0,948 & & \\
\hline BI3 & & 0,919 & & \\
\hline PEOU1 & & & 0,978 & \\
\hline PEOU2 & & & 0,978 & \\
\hline PEOU3 & & & 0,967 & \\
\hline PEOU4 & & & 0,936 & \\
\hline PEOU5 & & & 0,934 & \\
\hline PEOU6 & & & 0,986 & \\
\hline PU1 & & & & 0,835 \\
\hline PU2 & & & & 0,924 \\
\hline PU3 & & & & 0,896 \\
\hline PU4 & & & & 0,947 \\
\hline PU5 & & & & 0,959 \\
\hline PU6 & & & & 0,967 \\
\hline Sumber: Data & & & \\
\hline
\end{tabular}

Sumber: Data Olahan SmartPLS

Berdasarkan pada output outer loadings dapat dilihat bahwa hasil loading factor semua indikator untuk masing-masing konstruk sudah memenuhi convergent validity, karena semua nilai loading factor setiap indikator sudah di atas 0,50.

Discriminant validity dari indikator refleksif dapat dilihat pada cross loading antara indikator dengan konstruknya. Output cross loading hasil dari output PLS Algorithm dapat dilihat pada Tabel 4.3. 
Tabel 4.3

Output Cross Loading

\begin{tabular}{|l|c|c|c|c|}
\hline & ATB & BI & PEOU & PU \\
\hline ATB1 & $\mathbf{0 , 6 3 7}$ & 0,523 & 0,551 & 0,541 \\
\hline ATB2 & $\mathbf{0 , 9 4 8}$ & 0,941 & 0,929 & 0,948 \\
\hline ATB3 & $\mathbf{0 , 7 5 9}$ & 0,664 & 0,631 & 0,718 \\
\hline & ATB & BI & PEOU & PU \\
\hline ATB4 & $\mathbf{0 , 9 3 5}$ & 0,916 & 0,971 & 0,923 \\
\hline BI1 & 0,870 & $\mathbf{0 , 9 5 4}$ & 0,860 & 0,909 \\
\hline BI2 & 0,922 & $\mathbf{0 , 9 4 8}$ & 0,908 & 0,945 \\
\hline BI3 & 0,865 & $\mathbf{0 , 9 1 9}$ & 0,910 & 0,862 \\
\hline PEOU1 & 0,935 & 0,919 & $\mathbf{0 , 9 7 8}$ & 0,937 \\
\hline PEOU2 & 0,924 & 0,906 & $\mathbf{0 , 9 7 8}$ & 0,936 \\
\hline PEOU3 & 0,936 & 0,912 & $\mathbf{0 , 9 6 7}$ & 0,940 \\
\hline PEOU4 & 0,912 & 0,924 & $\mathbf{0 , 9 3 6}$ & 0,923 \\
\hline PEOU5 & 0,868 & 0,906 & $\mathbf{0 , 9 3 4}$ & 0,865 \\
\hline PEOU6 & 0,939 & 0,916 & $\mathbf{0 , 9 8 6}$ & 0,934 \\
\hline PU1 & 0,817 & 0,766 & 0,740 & $\mathbf{0 , 8 3 5}$ \\
\hline PU2 & 0,874 & 0,864 & 0,903 & $\mathbf{0 , 9 2 4}$ \\
\hline PU3 & 0,807 & 0,882 & 0,812 & $\mathbf{0 , 8 9 6}$ \\
\hline PU4 & 0,927 & 0,946 & 0,921 & $\mathbf{0 , 9 4 7}$ \\
\hline PU5 & 0,948 & 0,923 & 0,952 & $\mathbf{0 , 9 5 9}$ \\
\hline PU6 & 0,955 & 0,939 & 0,955 & $\mathbf{0 , 9 6 7}$ \\
\hline Sumber & D 2019 & \\
\hline
\end{tabular}

Sumber: Data Olahan SmartPLS

Berdasarkan Tabel 4.3 dapat dilihat bahwa korelasi masing-masing indikator dengan konstruknya lebih tinggi daripada dengan konstruk lain. Hal ini menunjukan bahwa konstruk laten memprediksi indikator pada bloknya sendiri lebih baik dibandingkan dengan indikator di blok lain

Selain uji validitas konstruk, pengujian outer model juga melakukan uji reliabilitas konstruk yang diukur dengan dua kriteria yaitu composite reliability dan croncbach alpha dari blok indikator yang mengukur konstruk. Konstruk dinyatakan reliabel jika nilai composite reliability maupun cronbach alpha di atas 0,70 (Ghozali, 2006: 43). Output composite reliability dan cronbach alpha dapat dilihat pada Tabel 4.4. 
Tabel 4.4

Output Composite Reliability dan Cronbach Alpha

\begin{tabular}{|l|c|c|}
\hline & $\begin{array}{c}\text { Cronbach's } \\
\text { Alpha }\end{array}$ & $\begin{array}{c}\text { Composite } \\
\text { Reliability }\end{array}$ \\
\hline ATB & 0,842 & 0,896 \\
\hline BI & 0,935 & 0,958 \\
\hline PEOU & 0,984 & 0,987 \\
\hline PU & 0,964 & 0,972 \\
\hline
\end{tabular}

Sumber: Data Olahan SmartPLS

Berdasarkan kedua Tabel 4.4 dapat diketahui bahwa nilai composite reliability dan cronbach alpha masing-masing konstruk sudah di atas 0,70. Jadi, dapat disimpulkan bahwa masing-masing konstruk sudah memiliki reliabilitas yang baik.

\section{b. Pengujian Inner Model}

Pengujian model structural atau inner model yang dilakukan dengan melihat nilai R Square pada konstruk endogen yang merupakan uji goodness-fit model. Model struktural yang memiliki hasil R Square sebesar 0,67 mengindikasikan bahwa model "baik", R Square sebesar 0,33 mengindikasikan bahwa model "moderat", dan R Square sebesar 0,19 mengindikasikan bahwa model "lemah" (Ghozali, 2006: 27). Nilai R Square masing-masing konstruk endogen dari estimasi model dapat dilihat pada Tabel 4.5.

Tabel 4.5

\section{Output R Square}

\begin{tabular}{|l|c|}
\hline & R Square \\
\hline ATB & 0,942 \\
\hline BI & 0,931 \\
\hline PU & 0,918 \\
\hline
\end{tabular}

Sumber: Data Olahan SmartPLS

Berdasarkan hasil output R-square pada Tabel 4.5 mengidentifikasikan bahwa terdapat ketiga konstruk yang termasuk kategori model "baik". Interpretasi dari output R Square dapat dijelaskan sebagai berikut :

1. Nilai R Square konstruk endogen ATB pada model penelitian ini sebesar 0,942. Hal ini berarti konstruk PU dan PEOU dapat menjelaskan konstruk ATU sebesar 94,2\% dan sisanya dijelaskan oleh variabel lain di luar model. 
2. Nilai R Square konstruk endogen PU pada model penelitian ini sebesar 0,918. Hal ini berarti konstruk PEOU dapat menjelaskan konstruk PU sebesar 91,8\% dan sisanya dijelaskan oleh variabel lain di luar model.

3. Nilai R Square konstruk endogen BI pada model penelitian ini sebesar 0,931. Hal ini berarti konstruk ATB dapat menjelaskan konstruk BI sebesar 94,2\% dan sisanya dijelaskan oleh variabel lain di luar model.

\section{Pengujian Hipotesis}

Pengujian hipotesis antar konstruk yaitu konstruk eksogen terhadap konstruk endogen dan konstruk endogen terhadap konstruk endogen dilakukan dengan metode resampling bootsrap. Statistik uji yang digunakan adalah statistic $\mathrm{t}$ atau uji $\mathrm{t}$. Nilai $\mathrm{t}$ pembanding dalam penelitian ini diperoleh dari tabel $t$. Nilai t-tabel dengan derajat kebebasan (dk) sebesar 98 dan taraf signifikansi sebesar 5\% diperoleh sebesar 1,994.

Pengujian hipotesis dilakukan dengan melihat output path coefficient dari hasil resampling bootstrap yang dapat dilihat pada Tabel 4.6.

Tabel 4.6

Output Path Coefficient

\begin{tabular}{|l|c|c|c|}
\hline & Original Sample (O) & $\begin{array}{c}\text { T Statistics } \\
(|\mathbf{O} / \mathbf{S T D E V}|)\end{array}$ & Keterangan \\
\hline ATB $->$ BI & 0,182 & 1,517 & Ha ditolak \\
\hline PEOU -> ATB & 0,365 & 3,909 & Ha diterima \\
\hline PEOU -> PU & 0,958 & 115,328 & Ha diterima \\
\hline PU -> ATB & 0,615 & 6,599 & Ha diterima \\
\hline PU -> BI & 0,788 & 6,737 & Ha diterima \\
\hline
\end{tabular}

Sumber: Data Olahan SmartPLS

1. Pengaruh PEOU terhadap PU. Hipotesis yang diajukan pada penelitian ini adalah:

a. Ho : Tidak terdapat pengaruh positif antara PEOU terhadap dalam PU

b. Ha : Terdapat pengaruh positif antara PEOU terhadap dalam PU

Output path coefficients dari hubungan konstruk PEOU dan PU dapat Tabel 4.6 menunjukkan adanya pengaruh positif antara konstruk PEOU terhadap PU dengan nilai koefisien sebesar 0,958 dan signifikan pada taraf 5\%. Hal ini dibuktikan dari 
besarnya $\mathrm{t}$ statistik untuk konstruk PEOU terhadap PU di atas 1,994 yaitu sebesar 115,328. Jadi dapat disimpulkan bahwa Ha diterima.

2. Pengaruh PU terhadap ATB. Hipotesis yang diajukan pada penelitian ini adalah :

a. Ho : Tidak terdapat pengaruh positif antara PU terhadap dalam ATB

b. Ha : Terdapat pengaruh positif antara PU terhadap dalam ATB

Output path coefficients dari hubungan konstruk PU dan ATB dapat Tabel 4.6 menunjukkan adanya pengaruh positif antara konstruk PU terhadap ATB dengan nilai koefisien sebesar 0,615 dan signifikan pada taraf 5\%. Hal ini dibuktikan dari besarnya $\mathrm{t}$ statistik untuk konstruk PU terhadap ATB di atas 1,994 yaitu sebesar 6,599. Jadi dapat disimpulkan bahwa Ha diterima.

3. Pengaruh PEOU terhadap ATB. Hipotesis yang diajukan pada penelitian ini adalah :

a. Ho : Tidak terdapat pengaruh positif antara PEOU terhadap dalam ATB

b. Ha : Terdapat pengaruh positif antara PEOU terhadap dalam ATB

Output path coefficients dari hubungan konstruk PEOU dan ATB dapat Tabel 4.6 menunjukkan adanya pengaruh positif antara konstruk PEOU terhadap ATB dengan nilai koefisien sebesar 0,365 dan signifikan pada taraf 5\%. Hal ini dibuktikan dari besarnya t statistik untuk konstruk PEOU terhadap ATB di atas 1,994 yaitu sebesar 3,909. Jadi dapat disimpulkan bahwa Ha diterima.

4. Pengaruh PU terhadap BI. Hipotesis yang diajukan pada penelitian ini adalah:

a. Ho : Tidak terd apat pengaruh positif antara PU terhadap dalam BI

b. Ha : Terdapat pengaruh positif antara PU terhadap dalam BI

Output path coefficients dari hubungan konstruk PU dan BI dapat Tabel 4.6 menunjukkan adanya pengaruh positif antara konstruk PU terhadap BI dengan nilai koefisien sebesar 0,788 dan signifikan pada taraf 5\%. Hal ini dibuktikan dari besarnya t statistik untuk konstruk PU terhadap BI di atas 1,994 yaitu sebesar 6,737. Jadi dapat disimpulkan bahwa Ha diterima.

5. Pengaruh ATB terhadap BI. Hipotesis yang diajukan pada penelitian ini adalah:

a. Ho : Tidak terdapat pengaruh positif antara ATB terhadap dalam BI

b. Ha : Terdapat pengaruh positif antara ATB terhadap dalam BI

Output path coefficients dari hubungan konstruk ATB dan BI dapat Tabel 4.6 menunjukkan adanya pengaruh positif dan tidak signifikan antara konstruk ATB 
terhadap BI dengan nilai koefisien sebesar 0,182 dan signifikan pada taraf 5\%. Hal ini dibuktikan dari besarnya t statistik untuk konstruk ATB terhadap BI di bawah 1,994 yaitu sebesar 1,517. Jadi dapat disimpulkan bahwa Ha ditolak.

\section{Pembahasan}

Berdasarkan pengujian hipotesis maka dapat dijelaskan sebagai berikut:

1. Pengaruh PEOU terhadap PU

Berdasarkan pengujian hipotesis pertama diketahui bahwa $\mathrm{H} 1$ yang diajukan dapat diterima. Output path coefficients menunjukkan bahwa nilai $\mathrm{t}$ statistik untuk konstruk PEOU terhadap konstruk PU di atas 1,994 yaitu sebesar 115,328 sehingga pengaruh yang diberikan oleh PEOU terhadap konstruk PU terbukti signifikan. Nilai koefisien variabel laten PEOU pada output path coefficients sebesar 0,958 yang berarti terdapat pengaruh positif sebesar $95,8 \%$ terhadap konstruk PU.

Semakin tinggi persepsi kemudahan penggunaan sistem aplikasi android Book Keeper Accounting maka akan semakin tinggi pula persepsi kegunaan sistem tersebut. Secara logis dapat dipersepsikan bahwa sistem yang semakin mudah digunakan akan lebih memberi manfaat dan kegunaan.

2. Pengaruh PU terhadap ATB

Berdasarkan pengujian hipotesis kedua diketahui bahwa $\mathrm{H} 2$ yang diajukan dapat diterima. Output path coefficients menunjukkan bahwa nilai $\mathrm{t}$ statistik untuk konstruk PU terhadap konstruk ATB di atas 1,994 yaitu sebesar 6,599 sehingga pengaruh yang diberikan oleh PU terhadap konstruk ATB terbukti signifikan. Nilai koefisien variabel laten PU pada output path coefficients sebesar 0,615 yang berarti terdapat pengaruh positif sebesar $61,5 \%$ terhadap konstruk ATB.

Semakin tinggi persepsi kegunaan sistem aplikasi and roid Book Keeper Accounting maka akan semakin tinggi pula sikap terhadap perilaku penggunaan sistem tersebut. Secara logis dapat dipersepsikan bahwa sistem yang semakin banyak memberikan manfaat atau kegunaan kepada pengguna akan mempengaruhi sikap terhadap perilaku pengguna untuk menggunakan aplikasi android Book Keeper Accounting. 
3. Pengaruh PEOU terhadap ATB

Berdasarkan pengujian hipotesis ketiga diketahui bahwa $\mathrm{H} 3$ yang diajukan dapat diterima. Output path coefficients menunjukkan bahwa nilai t statistik untuk konstruk PEOU terhadap konstruk ATB di atas 1,994 yaitu sebesar 3,909 sehingga pengaruh yang diberikan oleh PEOU terhadap konstruk ATB terbukti signifikan. Nilai koefisien variabel laten PEOU pada output path coefficients sebesar 0,365 yang berarti terdapat pengaruh positif sebesar 36,5\% terhadap konstruk ATB.

Semakin tinggi persepsi kemudahan penggunaan sistem aplikasi android Book Keeper Accounting maka akan semakin tinggi pula sikap terhadap perilaku penggunaan sistem tersebut. Secara logis dapat dipersepsikan bahwa sistem yang semakin mudah digunakan akan mempengaruhi sikap terhadap perilaku pengguna untuk menggunakan aplikasi android Book Keeper Accounting.

4. Pengaruh PU terhadap BI

Berdasarkan pengujian hipotesis keempat diketahui bahwa $\mathrm{H} 4$ yang diajukan dapat diterima. Output path coefficients menunjukkan bahwa nilai t statistik untuk konstruk PU terhadap konstruk BI di atas 1,994 yaitu sebesar 6,737 sehingga pengaruh yang diberikan oleh PU terhadap konstruk BI terbukti signifikan. Nilai koefisien variabel laten PU pada output path coefficients sebesar 0,788 yang berarti terdapat pengaruh positif sebesar $78,8 \%$ terhadap konstruk BI.

Semakin tinggi persepsi kegunaan sistem aplikasi android Book Keeper Accounting maka akan semakin tinggi pula minat perilaku penggunaan sistem tersebut. Secara logis dapat dipersepsikan bahwa sistem yang semakin banyak memberikan manfaat atau kegunaan kepada pengguna akan mempengaruhi minat perilaku pengguna untuk menggunakan aplikasi android Book Keeper Accounting.

5. Pengaruh ATB terhadap BI

Berdasarkan pengujian hipotesis kelima diketahui bahwa H5 yang diajukan ditolak. Output path coefficients menunjukkan bahwa nilai $\mathrm{t}$ statistik untuk konstruk ATB terhadap konstruk BI di bawah 1,994 yaitu sebesar 1,517 sehingga pengaruh yang diberikan oleh PU terhadap konstruk BI tidak terbukti signifikan. Nilai koefisien variabel laten PU pada output path coefficients sebesar 0,182 yang berarti terdapat pengaruh positif sebesar $18,2 \%$ terhadap konstruk BI. 
Sikap terhadap perilaku penggunaan sistem aplikasi android Book Keeper Accounting tidak mempengaruhi minat perilaku penggunaan sistem tersebut. Secara logis dapat dipersepsikan bahwa sikap terhadap perilaku pengguna tidak berpengaruh terhadap minat perilaku pengguna untuk menggunakan aplikasi android Book Keeper Accounting. Aplikasi android Book Keeper Accounting tidak menarik minat pemilik UMKM di Kota Pontianak untuk menggunakan sistem tersebut. Tidak adanya minat penggunaan aplikasi android Book Keeper Accounting oleh pemilik UMKM dapat disebabkan oleh kurang tingginya faktor-faktor sikap terhadap perilaku penggunaan sebelumnya.

\section{KESIMPULAN}

Berdasarkan hasil penelitian dan pembahasan faktor-faktor penerimaan penggunaan aplikasi android Book Keeper Accounting maka dapat disimpulkan sebagai berikut:

1. Konstruk kemudahan pengguna persepsian (perceived ease of use/PEOU) berpengaruh positif dan signifikan terhadap konstruk persepsian kegunaan (perceived usefulness/PU) sebesar 95,8\%. Selain itu, koefisien variabel laten pada konstruk ini memiliki nilai paling besar di antara nilai koefisien variabel laten pada model hubungan antar konstruk lainnya

2. Konstruk persepsian kegunaan (perceived usefulness/PU) berpengaruh positif dan signifikan terhadap konstruk sikap terhadap perilaku penggunaan teknologi (attitude towards behavior/ATB) sebesar 61,5\%.

3. Konstruk kemudahan pengguna persepsian (perceived ease of use/PEOU) berpengaruh positif dan signifikan terhadap konstruk sikap terhadap perilaku penggunaan teknologi (attitude towards behavior/ATB) sebesar 36,5\%.

4. Konstruk persepsian kegunaan (perceived usefulness/PU) berpengaruh positif dan signifikan terhadap konstruk minat perilaku penggunaan teknologi (behavior intention/BI) sebesar 78,8\%.

5. Konstruk sikap terhadap perilaku penggunaan teknologi (attitude towards behavior/ATB) tidak berpengaruh positif dan signifikan terhadap konstruk minat perilaku penggunaan teknologi (behavior intention/BI) sebesar 18,2\%. 
Penelitian ini memberikan saran sebagai berikut :

1. Saran Metodologis

Pengaruh kemudahan pengguna persepsian (perceived ease of use/PEOU) dan persepsian kegunaan (perceived usefulness/PU) terhadap sikap terhadap perilaku penggunaan teknologi (attitude towards behavior/ATB) sebaiknya mempunyai nilai yang tinggi. Peningkatan pengaruh kedua faktor tersebut dapat mendorong minat perilaku penggunaan teknologi (behavior intention/BI).

2. Saran Praktis

Berdasarkan simpulan maka dapat disarankan bahwa semakin terbiasa pemilik UMKM menggunakan aplikasi android Book Keeper Accounting akan meningkatkan minat perilaku penggunaan teknologi. Pemilik UMKM akan semakin mengerti kemudahan dan manfaat yang diperoleh apabila terbiasa menggunakan aplikasi android Book Keeper Accounting. 


\section{DAFTAR PUSTAKA}

Abdul Kadir. 2002. Pengenalan Sistem Informasi. Andi. Yogyakarta.

Ajzen, I. 1991. The Theory of Planned Behavior. Organizational Behavior and Human Decision Processes (50:2), pp. 179-211.

Ananggadipa. 2012. Studi Empiris pada Penggunaan Aplikasi Pajak: Integrasi Theory of Planned Behavior dan Technology Acceptance Model (Studi Empiris pada Perusahaan Go Public di Indonesia. Skripsi. Universitas Diponegoro.

Chin, W. W. 1998. The Partial Least Square Approach to Structural Equation Modeling. In Modern Methods for Business Research (pp. 295, 336).

Davis, F. 1986. A Technology Acceptance Model for Empirically Testing New End-user Information Systems: Theory and Result. In Doctoral dissertation Sloan School of Management MIT.

Davis, F. 1989. Perceived Usefulness, Perceived Ease of Use, and User Acceptance of Information Technology. MIS Quarterly (13:3), pp. 319-339.

Dreana, T. 2012. Analisis Faktor-Faktor yang Mempengaruhi Penerimaan Pengguna SIMAWEB di Fakultas Ekonomika dan Bisnis Universitas Diponegoro: Integrasi TAM dan TPB. Skripsi. Universitas Diponegoro.

Ghozali, I. 2011. Structural Equation Modeling, Metode Alternatif dengan Partial Least Square. Semarang: Badan Penerbit Universitas Diponegoro.

Igbaria, M., Guimaraes, T., \& Davis, G.B. (1995). Testing the Determinants of Microcomputer Usage via a Structural Equation Model. Journal of Management Information Systems (11) (pp. 87-114).

Jogiyanto, Hartono. 2008. Sistem Informasi Keperilakuan Edisi Revisi. Yogyakarta: Penerbit Andi.

Jogiyanto, Hartono. 2009. Analisis dan Desain Sistem Informasi, Edisi III. Yogyakarta: Penerbit Andi.

Mcleod, Raymond. 2001. Sistem Informasi Manajemen. Jakarta. PT. Prenhallindo.

Rainer, R. Kelly \& Cegleski, Casey G. 2001. Introduction to Information System. WileyPlus. 
www.indotelko.com. 2016. Penjualan Smartphone di 2016 Tumbuh 21\%.2016. http://www.indotelko.com/kanal?c=in\&it=penjualan-smartphone-2016-tumbuh$\underline{21}$ diunduh 27 Juli 2016 